\title{
ANTIOXIDANT CAPACITY AND TOTAL PHENOLIC COMPOUNDS OF TWELVE SELECTED POTATO LANDRACE CLONES GROWN IN SOUTHERNCHILE
}

\author{
Kong Ah-Hen ${ }^{1}$, Carolina Fuenzalida ${ }^{2}$, Susan Hess $^{3}$, Andrés Contreras ${ }^{2}$, Antonio Vega-Gálvez ${ }^{4 *}$, \\ and Roberto Lemus-Mondaca ${ }^{4,5}$
}

Colored potatoes (Solanum tuberosum L.) provide a natural source of phytochemicals that help reduce the risk of diseases. However, there is a lack of information on the degree of variation of the antioxidant activity and polyphenolic contents of these native potatoes. Thus, the antioxidant activity (AA) and total phenolic content (TPC) of native Chilean potatoes were determined. Twelve potato landrace clones collected from established cultivations on Chiloe Island and Valdivia were selected. Total phenolic content and AA were compared with two commercial varieties, Shepody and Desirée. Total phenolic content was determined by the Folin-Ciocalteu method, and $\beta$-carotene bleaching was used to compare AA. The

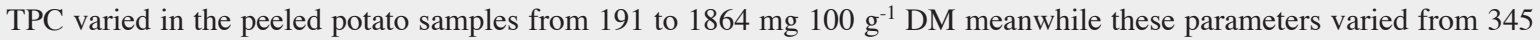

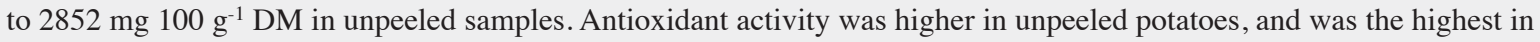
the unpeeled NG-6 or 'Bruja' native potato. The commercial var. Shepody showed pro-oxidant activity and had a relatively lower TPC. Results also indicated a higher concentration of total phenolics in the periderm of the colored native Chilean potatoes.

Key words: Chilean potatoes, Solanum tuberosum, antioxidant activity, total phenolics, Folin-Ciocalteu, $\beta$-carotene.

$\mathrm{T}$ he most widely cultivated variety of potato tubers, Solanum tuberosum Group Tuberosum, is indigenous to southern Chile. The cultivated genotypes on Chiloe Island show a wide variability in tuber shape, flesh and skin color, and flavor, as well as in storage and cooking quality. Published data on the degree of variation of antioxidant activity or phenolic content of these native potatoes is not known. As indicated by various studies, colored potatoes provide a natural source of phytochemicals such as carotenoids, phenolic compounds, flavonoids, and anthocyanins (Lewis et al., 1998a; 1998b; Reyes and Cisneros-Zevallos, 2003; Reyes et al., 2004) that help reduce the risk of chronic diseases, including cancer, agerelated neuronal degeneration, or cardiovascular diseases

\footnotetext{
${ }^{1}$ Universidad Austral de Chile, Instituto de Ciencia y Tecnología de los Alimentos, Av. Julio Sarrazín sn, Campus Isla Teja, Valdivia, Chile.

${ }^{2}$ Universidad Austral de Chile, Instituto de Producción y Sanidad Vegetal, Av. Eduardo Tallman sn, Campus Isla Teja, Valdivia, Chile. ${ }^{3}$ Universidad Austral de Chile, Instituto de Química, Las Encinas sn, Campus Isla Teja, Valdivia, Chile.

${ }^{4}$ Universidad de La Serena, Departamento de Ingeniería en Alimentos, Av. Raúl Bitrán sn, La Serena, Chile.

*Corresponding author (avegag@userena.cl).

${ }^{5}$ Universidad de Santiago de Chile, Departamento de Ingeniería Mecánica, Av. Bernardo O’Higgins 3363, Santiago, Chile.

Received: 12 August 2011.

Accepted: 27 December 2011.
}

(Ames et al., 1993; Hercberg et al., 1998; Velioglu et al., 1998; Tamimi et al., 2002).

The health-promoting effects of potatoes are also very promising for humans since a recent study showed that the consumption of unpeeled cooked potatoes improves the lipid metabolism and antioxidant status in cholesterolfed rats (Robert et al., 2006). Yellow-orange pigmented potatoes usually have high carotenoid contents, such as lutein, zeaxanthin, violaxanthin, and antheraxanthin (Brown, 2005; Andre et al., 2007). They are present in different proportions depending on the genotype and on storage conditions. Phenolic compounds, such as anthocyanins, are found in red-, blue-, or purple-fleshed potatoes (Brown, 2005). These include polyphenol, monohydric phenol, coumarin, flavonoid, tannin, and lignin (Lisinska and Leszczynski, 1989). Phenolic compounds such as chlorogenic, ferulic, caffeic, protocatechuic, and p-coumaric acids have been identified in red- or purple-fleshed potatoes (Lewis et al., 1998a). There are also small amounts o flavonoids such as rutin, quercetin, myricetin, naringenin, and kaempferol (Lewis et al., 1998b; Rodriguez-Saona et al., 1998; Reyes et al., 2005). The presence of these metabolites suggests that purple- and red-fleshed potatoes can be natural colorants or antioxidant sources for the food industry; however, a rigorous selection of genotypes with high antioxidant levels is needed. Phenolic acids, mainly chlorogenic acids, can consist of up to $90 \%$ of the total polyphenol content 
in potatoes (Andre et al., 2007). Phenolic compounds are mostly distributed between the potato cortex and skin (peel) tissues (Friedman, 1997). About 50\% of the phenolic compounds are located in the potato peel and adjoining tissues, while the rest decrease in concentration from the outside toward the center of potato tubers (Hasegawa et al., 1966).

In order to assess the condition of native Chilean potatoes, the main objective of this study was to examine some native colored potatoes from Chiloe Island for their total phenolic contents. Moreover, their antioxidant activity was also compared. The acquired information would serve as a criterion for selecting germplasm among native Chilean potatoes. For purposes of comparison, two commercial potato varieties commonly sold in local Chilean markets were selected as references.

\section{MATERIALS AND METHODS}

\section{Plant materials and sample preparation}

Twelve native Chilean potato genotypes were collected from established cultivations on Chiloe Island and at the Faculty of Agricultural Sciences, Universidad Austral de Chile, Valdivia, Chile. Shepody and Desirée, two commercial varieties, were purchased in local markets in Valdivia, to be used as references for purposes of comparison. The selected native potatoes are tetraploid and maintained as part of a germplasm collection of Chilean potatoes at the Universidad Austral de Chile (Contreras, 1987; Contreras and Castro, 2008). Identifier codes of the potato samples are given beside the traditional names in Table 1. Potato samples were all fresh and free of mechanical or physiological damage, and kept in the dark at $4{ }^{\circ} \mathrm{C}$ for a maximum period of $48 \mathrm{~h}$ until analyzed. Samples were then divided into two groups, peeled or unpeeled. For the peeled samples, about 1 to $2 \mathrm{~mm}$ layer of skin was carefully removed with a knife as it is usually done in any household. Samples were cut into small

Table 1. Total phenolic (TPC) and dry matter content in peeled native Chilean potatoes.

\begin{tabular}{|c|c|c|c|}
\hline \multirow{2}{*}{$\begin{array}{l}\text { Potato samples } \\
\text { Identifier code } \\
\text { (traditional name) }\end{array}$} & \multicolumn{2}{|c|}{ TPC content } & \multirow{2}{*}{$\begin{array}{c}\begin{array}{c}\text { Dry matter } \\
\text { content }\end{array} \\
\%\end{array}$} \\
\hline & $\mathrm{mg}_{\mathrm{DM}} 100 \mathrm{~g}^{-1}$ & $\begin{array}{l}\mathrm{mg} \mathrm{kg}^{-1} \\
\text { sample }\end{array}$ & \\
\hline Shepody & $192 \pm 26 a$ & $565 \pm 80 \mathrm{a}$ & $29.39 \pm 0.98 \mathrm{fg}$ \\
\hline Desirée & $302 \pm 31 b$ & $665 \pm 63 a$ & $22.06 \pm 1.52 \mathrm{ab}$ \\
\hline 457-CON-1157 (-) & $191 \pm 25 \mathrm{a}$ & $630 \pm 72 a$ & $33.06 \pm 0.70 \mathrm{~h}$ \\
\hline 254-CON-902 (Corazón de buey) & $409 \pm 41 c$ & $1248 \pm 134 b c$ & $30.50 \pm 0.55 \mathrm{~g}$ \\
\hline 302-UA-1634A (-) & $465 \pm 56 \mathrm{~cd}$ & $1221 \pm 161 b c$ & $26.26 \pm 0.53 \mathrm{cde}$ \\
\hline 304-UA-1135 (-) & $487 \pm 34 d$ & $1177 \pm 103 b$ & $24.15 \pm 0.63 b c$ \\
\hline 267-UA-1550 (Boyo de chancho) & $506 \pm 40 \mathrm{de}$ & $1241 \pm 112 b c$ & $24.53 \pm 0.51 \mathrm{~cd}$ \\
\hline NG-85 (Michuñeroja) & $529 \pm 36 \mathrm{de}$ & $1365 \pm 104 c$ & $25.81 \pm 0.83 \mathrm{cde}$ \\
\hline NG-71 (Meca de gato) & $563 \pm 61 \mathrm{ef}$ & $1564 \pm 178 d$ & $27.71 \pm 0.65 \mathrm{def}$ \\
\hline 283-UA-1108 (Cacho azul) & $629 \pm 65 f g$ & $1304 \pm 108 b c$ & $20.81 \pm 1.19 \mathrm{a}$ \\
\hline 301-UA-1500 (Corazón azul) & $668 \pm 64 \mathrm{gh}$ & $1708 \pm 144 d$ & $25.59 \pm 0.78 \mathrm{~cd}$ \\
\hline 239-UA-1388 (-) & $733 \pm 85 \mathrm{~h}$ & $2045 \pm 186 \mathrm{e}$ & $27.99 \pm 1.28 \mathrm{ef}$ \\
\hline NG-5 (Chona negra) & $945 \pm 88 \mathrm{i}$ & $2560 \pm 270 f$ & $27.07 \pm 1.16 \mathrm{f}$ \\
\hline NG-6 (Bruja) & $1864 \pm 129 j$ & $4757 \pm 273 g$ & $25.55 \pm 0.83 \mathrm{~g}$ \\
\hline
\end{tabular}

Means in a column with similar letters are not significantly different $(\mathrm{P}<0.05)$. pieces and washed thoroughly with distilled water and wiped with tissue paper to remove any adhering moisture. Samples were then kept frozen in labeled polyethylene bags and freeze-dried at $-55^{\circ} \mathrm{C}$ in a vacuum $(5 \mathrm{~mm} \mathrm{Hg})$ for $36 \mathrm{~h}$. All operations during sample preparation were performed very quickly by freeze-drying so as to avoid sample degradation. After freeze-drying and stabilization in a dessicator, samples were pulverized in a laboratory grinder. The cutting of samples was performed in a laboratory in an area especially adapted to give extra protection from sunlight with lightproof curtains. Frozen samples were kept at $-20{ }^{\circ} \mathrm{C}$ until analyzed. Care was taken to follow the same procedure for all samples, especially exposure time and elapsed time until analysis. Moisture content of all the samples was determined by a gravimetric standard method with a vacuum oven (Memmert UL 80, Büchenbach, Germany) and an analytical balance with an accuracy of $\pm 0.0001 \mathrm{~g}$ (Sartorius A200-CP224 S, Göttingen, Germany). All methodologies followed the recommendations of the Official Method of Analysis (AOAC, 1990) and all analyses were triplicated.

\section{Determining total phenolic content}

Total phenolic compounds were determined by the Folin-Ciocalteu photo-colorimetric method (Velioglu et al., 1998). A freeze-dried sample (200 mg), weighed accurately to $0.1 \mathrm{mg}$ on an analytical balance (Sartorius A200-CP224 S, Göttingen, Germany), was mixed with $2 \mathrm{~mL}$ of an aqueous solvent of $80 \%$ methanol acidified with $1 \% \mathrm{HCl}$ to extract the phenolic compounds. Protected from sunlight, the mixture was homogenized in a horizontal shaker (Shaker ZHWY 334 Zhicheng, Shanghai, China) at $200 \mathrm{rpm}$ for $2 \mathrm{~h}$ at room temperature. The liquid phase was separated with a Büchner funnel, a vacuum pump, and Whatman $\mathrm{N}^{\circ} 5$ filter paper. The filtrate was then centrifuged (Mini centrifuge, model 14, Denver Instrument Company, Denver, USA) in $2.5 \mathrm{~mL}$ Eppendorf tubes for $15 \mathrm{~min}$ at $7000 \mathrm{rpm}$. The supernatant was kept in dark glass vials from which an aliquot of $100 \mu \mathrm{L}$ was taken and mixed in a test tube with $750 \mu \mathrm{L}$ Folin-Ciocalteu reagent and left to stand for $5 \mathrm{~min}$. Next, $750 \mu \mathrm{L}$ of aqueous sodium bicarbonate solution $\left(60 \mathrm{~g} \mathrm{~L}^{-1}\right)$ was added and the mixture was allowed to stand for $90 \mathrm{~min}$ in the dark at a controlled temperature of $22^{\circ} \mathrm{C}$. Absorbance was measured at $725 \mathrm{~nm}$ with a UV-visible spectrophotometer (Spectrophotometer 300 Array, UV-Vis, single beam, Milton Roy, Ivyland, USA) and compared to a standard curve of ferulic acid $(0,50,100,150,200$, and $250 \mathrm{mg}$ $\mathrm{L}^{-1}$ ) to calculate total phenolics based on ferulic acid equivalents. All samples were assayed in quadruplicate.

\section{Determination of antioxidant activity}

Antioxidant activity of the potato extracts was evaluated by the $\beta$-carotene bleaching method as modified by Marco (1968) and described by Velioglu et al. (1998). A freeze-dried sample $(250 \mathrm{mg})$, weighed accurately to 0.1 
$\mathrm{mg}$, was extracted eight times with $6.25 \mathrm{~mL}$ of an aqueous

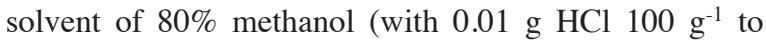
prevent degradation) in a dark glass vial and homogenized in a horizontal shaker (Shaker ZHWY 334 Zhicheng, Shanghai, China) at $200 \mathrm{rpm}$ at room temperature (15 min). The liquid phase was separated with a Büchner funnel, a vacuum pump, and Whatman $\mathrm{N}^{\circ} 5$ filter paper. All supernatants were combined. Antioxidant activity was immediately determined with aliquots of the filtrate $(0.2 \mathrm{~mL})$. In round-bottomed flasks, $1 \mathrm{~mL}$ of $\beta$-carotene solution (Sigma Chemical Co., St. Louis, Missouri, USA) and $0.2 \mathrm{mg} \mathrm{mL}^{-1}$ chloroform were mixed with $0.02 \mathrm{~mL}$ linoleic acid (J. T. Baker Chemical Co., Phillipsburg, New Jersey, USA) and $0.2 \mathrm{~mL}$ of Tween 20 (BDH Chemicals, Toronto, Canada). The mixture was then dosed with 0.2 $\mathrm{mL}$ of $80 \%$ methanol as a control or $0.2 \mathrm{~mL}$ of the potato extracts. After evaporation in a vacuum in a dark room, $50 \mathrm{~mL}$ of oxygenated deionized water was added and the mixture was shaken before being exposed to thermal oxidation at $50{ }^{\circ} \mathrm{C}$. Absorbance was then measured at 470 $\mathrm{nm}$ at 10-min intervals for $2 \mathrm{~h}$.

Antioxidant activity (AA) of phenolic compounds was expressed as percent inhibition with regard to a control with Equation [1], similar to the one Al-Saikhan et al. (1995) used, but with a modified bleaching rate $R_{t}$, which was calculated in accordance with first order kinetics as described in Equation [2]:

$$
A A=\frac{R_{c}-R_{s}}{R_{c}} \cdot 100
$$

where $R_{c}$ and $R_{s}$ are the $\beta$-carotene bleaching rate for the control and sample, respectively;

$$
\left(\mathrm{A}_{\mathrm{t}}-\mathrm{A}_{120}\right)=\left(\mathrm{A}_{0}-\mathrm{A}_{120}\right) \exp \left(-\mathrm{R}_{\mathrm{t}} \mathrm{t}\right)
$$

where $A_{0}, A_{120}$, and $A_{t}$ are absorbance at time 0,120 , and $t$ min, respectively. Calculation of $\mathrm{R}_{\mathrm{t}}$ for the control or sample considered absorbance at $120 \mathrm{~min}$ to be an equilibrium value so that the modified bleaching rate is related to an absorbance ratio based on the difference between initial and equilibrium absorbance.

\section{Statistical analysis}

Total phenolics were analyzed in quadruplicate on 15 tubers of each genotype. Values are expressed as means \pm standard deviation. Statistical analysis was performed with Stat Graphics Plus 5.1 (Statistical Graphics Corp., Herndon, Virginia, USA). Tukey's Honestly Significant Difference test was applied and the relevant minimum significant difference at a 95\% confidence interval $(\mathrm{P}<$ $0.05)$ to compare the significance of differences in means among potato samples. The coefficient of determination $\left(\mathrm{R}^{2}\right)$ showed the correlations between total phenolics and antioxidant activity.

\section{RESULTS AND DISCUSSION}

\section{Total phenolic content}

Typical phenolics with antioxidant activity are mainly phenolic acids and flavonoids, which are the major classes of phenolic compounds widely found in fruits and vegetables (Wojdylo et al., 2007). Total phenolic content (TPC) of the potato samples is shown in Tables 1 and 2. Dry matter content of the peeled and unpeeled samples is also given as a percentage of the fresh product since water content of the potato samples showed significant differences at $\mathrm{P}<0.05$. Total phenolic content in the peeled potato sample varied from $565 \pm 80 \mathrm{mg} \mathrm{kg}^{-1}$ in the commercial var. Shepody to $4757 \pm 273 \mathrm{mg} \mathrm{kg}^{-1}$ in the genotype NG-6 sample (traditionally known as 'Bruja'). In unpeeled potato samples, var. Shepody also had the lowest TPC and genotype 'Bruja' had the highest with $763 \pm 91$ and $7486 \pm 411 \mathrm{mg} \mathrm{kg}^{-1}$, respectively. Genotype 457-CON-1157 (from the Guaitecas Archipelago) had a TPC that was not significantly different at $\mathrm{P}<0.05$ than the two commercial varieties. It has red skin, similar to 'Desirée', but pale red pulp of the vascular ring. As a peeled sample, its TPC did not differ from 'Shepody'. Significant differences in TPC at $\mathrm{P}<0.05$ can be observed among the native potatoes; the 'Bruja' genotype showed an outstanding TPC at almost tenfold the commercial var. Shepody. Second on the list was genotype NG-5 (traditionally known as 'Chona negra') with about five times more TPC than 'Shepody'. In all cases, TPC in unpeeled potato samples are higher than in peeled samples, showing clearly that TPC is accumulated in the skin tissue. Similar results were also obtained by AlSaikhan et al. (1995), Reyes et al. (2005), and Nara et al. (2006). According to Nara et al. (2006), TPC in the flesh and skin have different compositions. They can be in a free or bound form. Chlorogenic acid and caffeic acid are the phenolic free forms reported in potatoes (Friedman, 1997; Kanatt et al., 2005), while ferulic acid and p-coumaric acid are the bound forms that are esterlinked to the cell wall polysaccharides of several plants (Fry, 1986). Nara et al. (2006) found that the free form of phenolics predominates over the bound form in both skin tissue and flesh (Table 3 ). The native Chilean potato

Table 2. Total phenolic (TPC) and dry matter content in unpeeled native Chilean potatoes.

\begin{tabular}{lcccc}
\hline & \multicolumn{2}{c}{ TPC content } & & Dry matter content \\
\cline { 2 - 3 } \cline { 5 - 5 } Potato samples & $\mathrm{mg} 100 \mathrm{~g}^{-1} \mathrm{DM}$ & $\mathrm{mg} \mathrm{kg}^{-1} \mathrm{sample}$ & & $\%$ \\
\hline Shepody & $260 \pm 30 \mathrm{a}$ & $763 \pm 91 \mathrm{a}$ & & $29.34 \pm 0.76 \mathrm{gh}$ \\
Desirée & $352 \pm 19 \mathrm{a}$ & $821 \pm 67 \mathrm{a}$ & & $23.30 \pm 1.04 \mathrm{ab}$ \\
457-CON-1157 & $345 \pm 19 \mathrm{a}$ & $1141 \pm 81 \mathrm{~g}$ & & $33.08 \pm 0.87 \mathrm{i}$ \\
267-UA-1550 & $560 \pm 52 \mathrm{~b}$ & $1432 \pm 129 \mathrm{f}$ & & $25.55 \pm 0.29 \mathrm{~cd}$ \\
302-UA-1634A & $571 \pm 55 \mathrm{~b}$ & $1491 \pm 159 \mathrm{f}$ & & $26.10 \pm 0.55 \mathrm{cde}$ \\
254-CON-902 & $601 \pm 48 \mathrm{~b}$ & $1855 \pm 145 \mathrm{f}$ & & $30.86 \pm 0.61 \mathrm{~h}$ \\
304-UA-1135 & $726 \pm 66 \mathrm{c}$ & $1755 \pm 153 \mathrm{e}$ & & $24.20 \pm 0.27 \mathrm{bc}$ \\
NG-71 & $745 \pm 41 \mathrm{c}$ & $2061 \pm 108 \mathrm{e}$ & & $27.55 \pm 0.51 \mathrm{efg}$ \\
301-UA-1500 & $780 \pm 84 \mathrm{~cd}$ & $2011 \pm 212 \mathrm{de}$ & & $25.78 \pm 0.55 \mathrm{cde}$ \\
NG-85 & $844 \pm 74 \mathrm{de}$ & $2305 \pm 188 \mathrm{~cd}$ & & $27.33 \pm 0.83 \mathrm{defg}$ \\
239-UA-1388 & $850 \pm 60 \mathrm{de}$ & $2428 \pm 196 \mathrm{~cd}$ & & $28.57 \pm 1.09 \mathrm{~g}$ \\
283-UA-1108 & $879 \pm 74 \mathrm{e}$ & $1865 \pm 189 \mathrm{c}$ & & $21.19 \pm 1.19 \mathrm{a}$ \\
NG-5 & $1304 \pm 82 \mathrm{f}$ & $3684 \pm 315 \mathrm{~b}$ & & $28.24 \pm 1.65 \mathrm{fg}$ \\
NG-6 & $2852 \pm 202 \mathrm{~g}$ & $7486 \pm 411 \mathrm{a}$ & & $26.29 \pm 1.08 \mathrm{cdef}$ \\
\hline
\end{tabular}

Tukey's HSD test: Means in a column with similar letters are not significantly different $(\mathrm{P}<0.05)$. 
Table 3. Comparison of total phenolic content (TPC) in some varieties of potatoes as found in the literature.

\begin{tabular}{|c|c|c|c|c|}
\hline \multirow[b]{2}{*}{ Potato genotype or variety } & \multirow{2}{*}{$\begin{array}{l}\text { Equivalent acid } \\
\text { to calculate TPC }\end{array}$} & \multicolumn{2}{|c|}{$\mathrm{TPC}$} & \multirow[b]{2}{*}{ References } \\
\hline & & $\mathrm{mg} \mathrm{kg}^{-1}$ fresh product & $\mathrm{mg} 100 \mathrm{~g}^{-1} \mathrm{DM}$ & \\
\hline Yukon gold & Chlorogenic & 237.7 & $82^{1}$ & Al-Saikhan et al.(1995) \\
\hline Granola & Chlorogenic & 407.0 & $140^{1}$ & Al-Saikhan et al.(1995) \\
\hline Russet Norkotah & Chlorogenic & 527.2 & $182^{1}$ & Al-Saikhan et al.(1995) \\
\hline Viking & Chlorogenic & 369.1 & $127^{1}$ & Al-Saikhan et al.(1995) \\
\hline Purple potato & Ferulic & - & 781 & Velioglu et al. (1998) \\
\hline Russet Burbank & Ferulic & - & 437 & Velioglu et al. (1998) \\
\hline \multirow[t]{2}{*}{ All Blue } & Chlorogenic & Flesh: $125 \pm 11$ & Flesh: $43 \pm 38^{1}$ & \\
\hline & & Peel: $256 \pm 18$ & Peel: $88 \pm 62^{1}$ & Reyes et al.(2005) \\
\hline \multirow[t]{2}{*}{ NDC4069-4 } & Chlorogenic & Flesh: $116 \pm 14$ & Flesh: $40 \pm 48^{1}$ & \\
\hline & & Peel: $225 \pm 11$ & Peel: $78 \pm 381$ & Reyes et al.(2005) \\
\hline \multirow[t]{4}{*}{ Toyoshiro } & Ferulic & - & Flesh: 168 (free) & \\
\hline & & & Peel: 366 (free) & Nara et al. (2006) \\
\hline & & & Flesh: 2 (bound) & \\
\hline & & & Peel:126 (bound) & Nara et al. (2006) \\
\hline Valfi & Gallic & - & 481 & Lachman et al. (2008) \\
\hline Violette & Gallic & - & 455 & Lachman et al. (2008) \\
\hline Shetland Black, location Valečov & Chlorogenic & - & 99.0 & Hejtmánková et al. (2009) \\
\hline Vitelotte, location Stachy & Chlorogenic & - & 762.4 & Hejtmánková et al. (2009) \\
\hline
\end{tabular}

${ }^{1}$ Value calculated based on a dry matter content mean of $29 \%$ in fresh product.

genotypes have an above average TPC compared with other potatoes found in the literature (Table 3). Al-Saikhan et al. (1995) mentioned that potatoes are high in phenolic compounds ranging from 530 to $1770 \mathrm{mg} \mathrm{kg}^{-1}$ : however, they did not specify if it is based on fresh weight or DM. In many cases, TPC is expressed as chlorogenic acid equivalents. This is common in research since the free soluble phenols are determined using methanol, ethanol, and acetone either separately or mixed (Kahkonen et al., 1999; Bonoli et al., 2004). Since ferulic acid was used to quantify TPC in this study, only a relative comparison with literature data can be drawn. However, compared with Purple and Russet Burbank potatoes (Table 3 ) analyzed by Velioglu et al. (1998), a similar TPC level is found in 10 of the unpeeled native Chilean potatoes (Table 2). Purple potato TPC amounted to $781 \mathrm{mg} 100 \mathrm{~g}^{-1} \mathrm{DM}$, while its

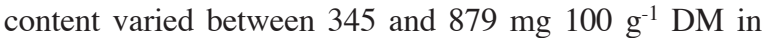
unpeeled Chilean potatoes; this indicates that two native Chilean potato genotypes have a remarkably high TPC.

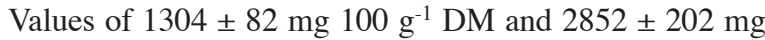
$100 \mathrm{~g}^{-1} \mathrm{DM}$ were obtained for the native genotypes 'Chona negra' and 'Bruja', respectively. In the unpeeled state, the commercial var. Desirée, red skin and pale yellow flesh,

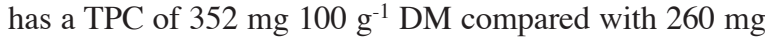
$100 \mathrm{~g}^{-1}$ DM in the commercial var. Shepody, which has a smooth to lightly netted white skin and white flesh. In

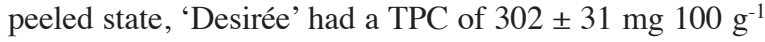
DM and 'Shepody' only $192 \pm 26 \mathrm{mg} 100 \mathrm{~g}^{-1} \mathrm{DM}$. The other native Chilean potatoes also had a lower TPC in the peeled state, which is consistent with the results obtained by Nara et al. (2006). Most of the total phenolics are found in the peel in a free or bound form (Table 3). The potato var. Vitelotte analyzed by Hejtmánková et al. (2009) showed high TPC in this respect and was similar to the Purple potato of Velioglu et al. (1998) along with three of the Chilean potato genotypes shown in Table 2. Moreover,
Onyeneho and Hettiaachchy (1993) evaluated the ability to prevent soybean oil oxidation of freeze-dried extracts taken from the peels of six potato varieties. They found that the peels from red potatoes contained greater amounts of polyphenols than those from brown-skinned varieties. Rodriguez de Sotillo et al. (1994a; 1994b) also found high amounts of phenolic compounds in potato peels and confirmed the strong antioxidant activity of freeze-dried extracts of potato peel waste in sunflower oil. These findings therefore suggest the possible value of the potato peel in the prevention of oxidative rancidity of food oils.

\section{Antioxidant capacity}

Antioxidant activity was determined in four of the native Chilean potato genotypes and in the two commercial varieties. Selection of the four samples was based on previous field studies as well as for the intense red, dark purple, and pink color. The 'Bruja' sample is a roundshaped potato with deep eye buds, dark purple periderm, and dark purple medulla with small yellow spots or flecks. The 301-UA-1500 ('Corazón azul') sample is also roundshaped potato with deep eye buds, red purplish skin, and predominantly red purplish medulla with a white and red purplish cortex. The 267-UA-1550 ('Boyo de chancho') sample is a curved oblong shaped potato with shallow to deep yellow eye buds, dark purple skin color, and yellow medulla with an irregular distribution of purple pigmentation that becomes more intense towards the stem end. The 239-UA-1388 sample has no traditional name, is round-shaped potato with very deep eye buds, a mainly pink periderm with a secondary creamy yellow color, and pink medulla with some creamy yellow flecks.

The $\beta$-carotene bleaching method was used whereby the antioxidant activity is measured by a compound's ability to minimize $\beta$-carotene loss during the simultaneous oxidation of linoleic acid and $\beta$-carotene in 
an emulsified aqueous system. This method is rapid and simple and can be used to compare the antioxidant activity of compounds with different structures (Fukumoto and Mazza, 2000). The reaction is initiated with heat at 50 ${ }^{\circ} \mathrm{C}$. Figure 1 shows the decrease in $\beta$-carotene absorbance in the different methanolic potato extracts caused by $\beta$-carotene and linoleic acid oxidation. The curves show a logarithmical tendency that is confirmed by the straight line graph in Figure 2 where the natural logarithm of modified bleaching rate $\left(\mathrm{R}_{\mathrm{t}}\right)$ is plotted against reaction or incubation time. The gradient of the curve in Figure 1 indicates the $\beta$-carotene oxidation rate and shows that after any reaction time t (0 to $120 \mathrm{~min})$, sample 'Bruja'

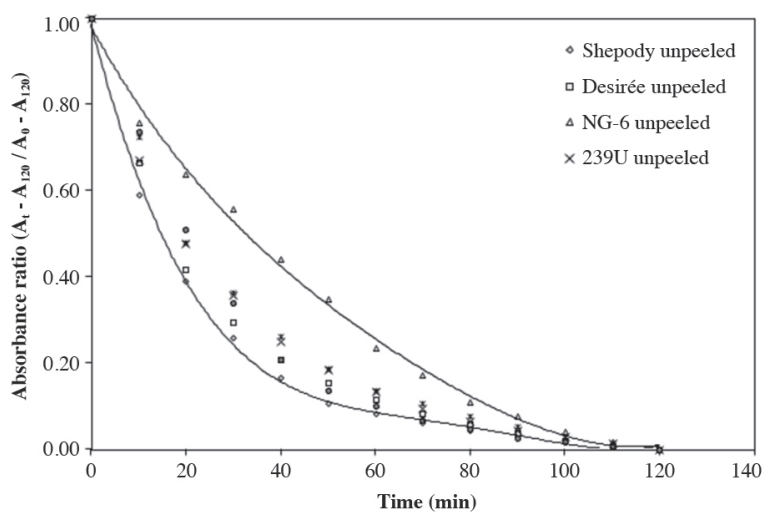

Figure 1. Antioxidant activity of two commercial potato varieties and unpeeled native Chilean potatoes genotypes assayed by the $\beta$-carotene bleaching method.

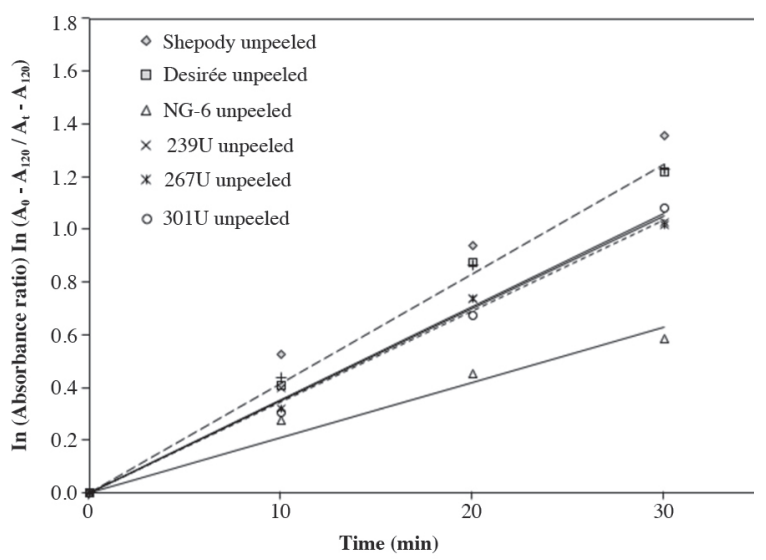

Figure 2. $\beta$-Carotene bleaching rate at $50{ }^{\circ} \mathrm{C}$ on native Chilean potato extracts. or NG-6 have a stronger retarding effect on $\beta$-carotene oxidation than the 'Shepody' sample. High coefficients of determination $\mathrm{R}^{2}$ were obtained in all cases for variation of absorbance with reaction time (Table 4). The unpeeled 'Bruja' genotype showed the highest antioxidant activity. The peeled commercial var. Shepody exhibited the lowest antioxidant activity. With regard to the control, it even showed a pro-oxidant activity, which may be due to the antagonist effect of phenolic compounds. According to Peyrat-Maillard et al. (2003) and Samotyja and Malecka (2007), antagonism has been observed between $\alpha$-tocopherol and caffeic acid, between catechin and caffeic acid, or between caffeic acid and quercetin. These phenolics are known to occur in potatoes (Friedman, 1997; Kanatt et al., 2005). It is also known that compounds with antioxidant activity can exhibit pro-oxidant behavior under certain conditions (Fukumoto and Mazza, 2000). Ascorbic acid, a potato component, showed pro-oxidant activity at a concentration of $0.320 \mathrm{mg} \mathrm{mL}^{-1}$ during a $\beta$-carotene bleaching assay (Al-Saikhan et al., 1995).

A maximum difference is observed in $\beta$-carotene bleaching after a reaction time of $30 \mathrm{~min}$ (Figure 2) so that antioxidant activity (Equation [1]) was computed for the control based on a modified bleaching rate for that reaction time (Equation [2]). Table 4 shows the antioxidant activity of the four native Chilean potato genotypes and the two commercial varieties obtained from local markets. On the average, the two commercial varieties showed prooxidant activity. The peeled 267-UA-1550 genotype (traditionally known as 'Boyo de chancho') exhibited the lowest antioxidant activity, indicating that antagonistic phenolics probably predominate in the flesh of that sample. Nevertheless, a higher antioxidant capacity is observed in whole potatoes in all the samples. This clearly demonstrates a high nutritional value of the potato peel that is generally discarded during meal preparation. However, compared with antioxidant standards such as BHT or $\beta$-tocopherol that minimize $\beta$-carotene loss with an antioxidant activity of $97.2 \%$ and $97.3 \%$, respectively (Velioglu et al., 1998), three of the selected Chilean potato genotypes performed poorly. Genotype NG-6 differed remarkably with the highest antioxidant activity among the native Chilean potatoes.

Finally, antioxidant activity was correlated with TPC. The best positive correlation was found when considering only the native samples (Figure 3). A commonly

Table 4. Antioxidant activity (AA) and modified bleaching rate $\left(\mathbf{R}_{t}\right)$ for selected native Chilean potato samples.

\begin{tabular}{|c|c|c|c|c|c|c|}
\hline \multirow[b]{2}{*}{ Potato variety/genotype } & \multicolumn{3}{|c|}{ Unpeeled samples } & \multicolumn{3}{|c|}{ Peeled samples } \\
\hline & $\underset{\%}{\mathrm{AA}}$ & $\begin{array}{c}\mathrm{R}_{\mathrm{t}} \\
\min ^{-1}\end{array}$ & $\mathrm{R}^{2}$ & $\begin{array}{c}\mathrm{AA} \\
\%\end{array}$ & $\begin{array}{c}\mathrm{R}_{\mathrm{t}} \\
\min ^{-1}\end{array}$ & $\mathrm{R}^{2}$ \\
\hline Shepody & $-11 \pm 6$ & $0.0462 \pm 0.0027$ & 0.9945 & $-29 \pm 12$ & $0.0538 \pm 0.0049$ & 0.9560 \\
\hline Desirée & $0 \pm 6$ & $0.0416 \pm 0.0026$ & 0.9969 & $3 \pm 7$ & $0.0407 \pm 0.0029$ & 0.9901 \\
\hline NG-6 (Bruja) & $50 \pm 4$ & $0.0210 \pm 0.0018$ & 0.9606 & $11 \pm 2$ & $0.0372 \pm 0.0008$ & 0.9953 \\
\hline 239-UA-1388 & $15 \pm 12$ & $0.0354 \pm 0.0052$ & 0.9926 & $10 \pm 1$ & $0.0377 \pm 0.0006$ & 0.9812 \\
\hline 267-UA-1550 (Boyo de chancho) & $17 \pm 5$ & $0.0346 \pm 0.0021$ & 0.9950 & $4 \pm 2$ & $0.0403 \pm 0.0007$ & 0.9977 \\
\hline 301-UA-1500 (Corazón azul) & $16 \pm 2$ & $0.0351 \pm 0.0009$ & 0.9943 & $13 \pm 5$ & $0.0365 \pm 0.0020$ & 0.9877 \\
\hline Control & 0 & $0.0418 \pm 0.0027$ & 0.9977 & 0 & $0.0418 \pm 0.0027$ & 0.9977 \\
\hline
\end{tabular}




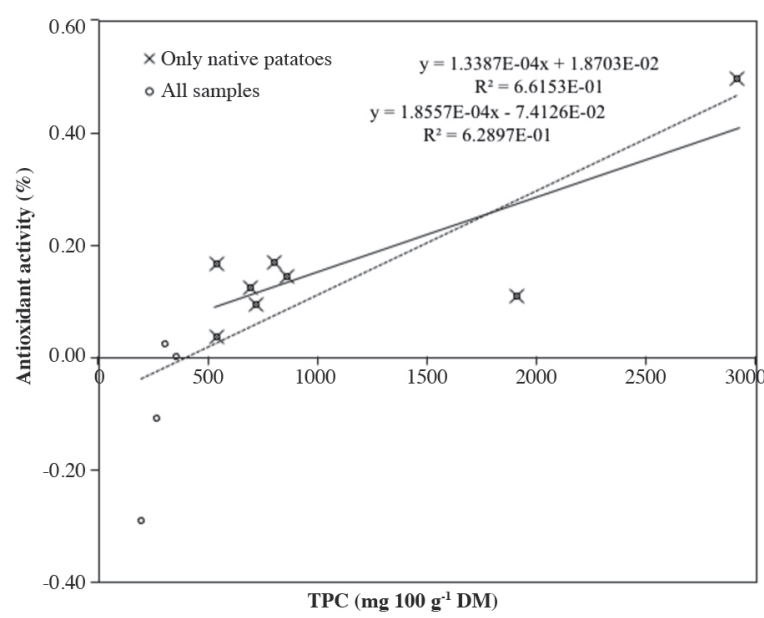

Figure 3. Relationship between total phenolic content (TPC) and antioxidant activity.

observed coefficient of determination $(0.66$ at $\mathrm{P}<0.05)$ was obtained for this relationship. Hejtmánková et al. (2009) obtained $\mathrm{R}^{2}$ values of 0.64 and 0.55 correlating percentage inhibition of ABTS [2,2'-azinobis(3-ethylbenzothiazoline-6-sulfonic acid)] with total anthocyanins and chlorogenic acid, respectively. Velioglu et al. (1998) found that anthocyanin-rich material will interfere in this relationship. High positive correlations between AA and TPC suggest that these compounds are mostly responsible for antioxidant activity.

\section{CONCLUSIONS}

Native Chilean potato genotypes have great potential as a source of total phenolics. The assays for TPC and antioxidant activity determined with the $\beta$-carotene bleaching method gave consistent results and these methods would be useful in a rapid selection of germplasm for a breeding program initiated in southern Chile. The identification of potato cultivars with high phenolic content adds value to potato consumption and might open new market niches for cultivated native species. In addition, these results support investment in new breeding programs to improve health-promoting nutrients in modern potato cultivars using native Chilean genotypes.

\section{ACKNOWLEDGEMENTS}

The authors gratefully acknowledge the financial support for project FIA-PIT 2007-2010 and to the Research Department of the Universidad Austral de Chile (DID2006-05).

Capacidad antioxidante y compuestos fenólicos totales de una selección de doce variedades tradicionales de papa cultivadas en la Región Sur de Chile. Las papas (Solanum tuberosum L.) coloreadas son una fuente natural de fitoquímicos que ayudan a reducir el riesgo de enfermedades. Sin embargo, existe una falta de información sobre el grado de variación de la actividad antioxidante y el contenido de polifenoles en estas papas nativas. Es así como la actividad antioxidante (AA) y contenido de fenoles totales (TPC) se determinaron en papas nativas chilenas. Doce genotipos de papa recogidos de cultivos establecidos en la Isla de Chiloé y en Valdivia fueron seleccionados, y se compararon TPC y AA con dos variedades comerciales, Shepody y Desirée. El TPC se determinó por el método de Folin-Ciocalteu, y el blanqueamiento de $\beta$-caroteno se utilizó para comparar la AA. El TPC varió en las muestras de papas sin piel desde

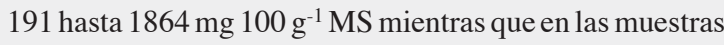
con piel estos valores varían entre 345 y $2852 \mathrm{mg} 100 \mathrm{~g}^{-1}$ MS. La AA fue mayor en las papas con piel, con el mayor valor para la papa nativa 'NG-6' o 'Bruja'. La variedad comercial Shepody mostró actividad prooxidante y tuvo un TPC relativamente más bajo. Los resultados también indicaron una mayor concentración de fenoles totales en la epidermis de las papas nativas chilenas.

Palabras clave: papas chilenas, Solanum tuberosum, actividad antioxidante, fenoles totales, Folin-Ciocalteu, $\beta$ -caroteno.

\section{LITERATURE CITED}

Al-Saikhan, M.S., L.R. Howard, and J.C. Miller. 1995. Antioxidant activity and total phenolics in different genotypes of potato (Solanum tuberosum L.). Journal of Food Science 60:341-347.

Ames, B.N., M.K. Shigenaga, and T.M. Hagen. 1993. Oxidants, Antioxidants and the degenerative diseases of aging. Proceedings of the National Academy of Sciences of the United States of America 90:7915-7922.

Andre, C.M., M. Ghislain, P. Bertin, M. Oufir, M.D. Herrera, L. Hoffmann, et al. 2007. Andean potato cultivars (Solanum tuberosum L.) as a source of antioxidant and mineral micronutrients. Journal of Agricultural and Food Chemistry 55:366-378.

AOAC. 1990. Official method of analysis. $15^{\text {th }}$ ed. Association of Official Analytical Chemists (AOAC), Washington D.C., USA.

Bonoli, M., V. Verardo, E. Marconi, and M. Caboni. 2004. Phenols in barley (Hordeum vulgare L.) flour: Comparative spectrophotometric study among extraction methods of free and bound phenolic compounds. Journal of Agricultural and Food Chemistry 52:5195-5200.

Brown, C. 2005. Antioxidants in potato. American Journal of Potato Research 82:163-172.

Contreras, A. 1987. Germoplasma chileno de papas. Recolección, mantención y evaluación. p. 43-75. In Contreras, A., y J. Esquinas (eds.) Actas Simposio Recursos Fitogenéticos, Valdivia 20-22. 1984. Universidad Austral de Chile UACH-International Board for Plant Genetic Resources IBPGR, Valdivia, Chile.

Contreras, A., e I. Castro. 2008. Catálogo de variedades de papa nativas de Chile. 234 p. Universidad Austral de Chile, Valdivia, Chile.

Friedman, M. 1997. Chemistry, biochemistry, and dietary role of potato polyphenols. A review. Journal of Agricultural and Food Chemistry 45:1523-1540.

Fry, S. 1986. Cross-linking of matrix polymers in the growing cell walls of angiosperms. Annual Review of Plant Physiology 37:165-186. 
Fukumoto, L., and G. Mazza. 2000. Assessing antioxidant and prooxidant activities of phenolic compounds. Journal of Agricultural and Food Chemistry 48:3597-3604.

Hasegawa, D., R.M. Johnson, and W.A. Gould. 1966. Effect of cold storage on chlorogenic acid content of potatoes. Journal of Agricultural Food Chemistry 14:165-169.

Hejtmánková, K., V. Pivec, E. Trnková, K. Hamouz, and J. Lachman. 2009. Quality of coloured varieties of potatoes. Czech Journal of Food Sciences 27:S310-S313.

Hercberg, S., P. Galan, P. Preziosi, M. Alfarez, and C. Vasquez. 1998. The potential role of antioxidant vitamins in preventing cardiovascular diseases and cancers. Nutrition 14:513-520.

Kahkonen, M., A. Hopia, H. Vuorela, J. Rauha, K. Pihlaja, T. Kujala, and M. Heinonen. 1999. Antioxidant activity of plant extracts containing phenolic compounds. Journal of Agricultural and Food Chemistry 47:3954-3962.

Kanatt, S., R. Chander, P. Radhakrishna, and A. Sharma. 2005. Potato peel extract - a natural antioxidant for retarding lipid peroxidation in radiation processed lamb meat. Journal of Agricultural and Food Chemistry 53:1499-1504.

Lachman, J., K. Hamouz, M. Orsák, V. Pivec, and P. Dvorák. 2008. The influence of flesh colour and growing locality on polyphenolic content and antioxidant activity in potatoes. Scientia Horticulturae 117:109-114.

Lewis, C., J. Walker, J. Lancaster, and K. Sutton. 1998a. Determination of anthocyanins, flavonoids and phenolic acids in potatoes. I. Coloured cultivars of Solanum tuberosum L. Journal of the Science of Food and Agriculture 77:45-57.

Lewis, C., J. Walker, J. Lancaster, and K. Sutton. 1998b. Determination of anthocyanins, flavonoids and phenolic acids in potatoes. II. Wild, tuberous Solanum species. Journal of the Science of Food and Agriculture 77:58-63.

Lisinska, G., and W. Leszczynski. 1989. Potato Science and Technology. 391 p. Elsevier Science Publishers Ltd., Barking, Essex, UK.

Marco, G. 1968. A rapid method for evaluation of antioxidants. Journal of the American Oil Chemical Society 45:594-598.

Nara, K., T. Miyoshi, T. Honma, and H. Koga. 2006. Antioxidative activity of bound-form phenolics in potato peel. Biosciences Biotechnology Biochemistry 70:1489-1491.

Onyeneho, S-N., and N.S. Hettiaachchy. 1993. Antioxidant activity, fatty acid and phenolic acid composition of potato peels. Journal of the Science of Food and Agriculture 62:345-350.
Peyrat-Maillard, M., M. Cuvelier, and C. Berset. 2003. Antioxidant activity of phenolic compounds in 2,2'-azobis (2-amidinopropane) dihydrochloride (AAPH)-induced oxidation: Synergistic and antagonistic effects. Journal of the American Oil Chemists Society 80:1007-1012

Reyes, L., and L. Cisneros-Zevallos. 2003. Wounding stress increases the phenolic content and antioxidant capacity of purplefleshed potatoes (Solanum tuberosum L.). Journal of Agricultural and Food Chemistry 51:5296-5300.

Reyes, L., J. Miller, and L. Cisneros-Zevallos. 2004. Environmental conditions influence the content and yield of anthocyanins and total phenolics in purple- and red-fleshed potatoes during tuber development. American Journal of Potato Research 81:187-193.

Reyes, L., J. Miller, and L. Cisneros-Zevallos. 2005. Antioxidant capacity, anthocyanins and total phenolics in purple- and redfleshed potato (Solanum tuberosum L.) genotypes. American Journal of Potato Research 82:271-277.

Robert, L., A. Narcy, E. Rock, C. Demigne, A. Mazur, and C. Rémésy. 2006. Entire potato consumption improves lipid metabolism and antioxidant status in cholesterol-fed rat. European Journal of Nutrition 45:267-274

Rodriguez de Sotillo, D., M. Hadley, and E.T. Holm. 1994a. Phenolics in aqueous potato peel extract: extraction, identification and degradation. Journal of Food Science 59:649-651.

Rodriguez de Sotillo, D., M. Hadley, and E.T. Holm. 1994b. Potato peel waste; stability and antioxidant activity of a freeze-dried extract. Journal of Food Science 59:1031-1033.

Rodriguez-Saona, L., M. Giusti, and R. Wrolstad. 1998. Anthocyanin pigment composition of red-fleshed potatoes. Journal of Food Science 63:458-465.

Samotyja, U., and M. Malecka. 2007. Effects of blackcurrant seeds and rosemary extracts on oxidative stability of bulk and emulsified lipid substrates. Food Chemistry 104:317-323.

Tamimi, R., P. Lagiou, H. Adami, and D. Trichopoulos. 2002. Prospects for chemoprevention of cancers. Journal of Internal Medicine 251:286-300

Velioglu, Y.S., G. Mazza, L. Gao, and B.D. Oomah. 1998. Antioxidant activity and total phenolics in selected fruits, vegetables, and grain products. Journal of Agricultural and Food Chemistry 46:41134117.

Wojdylo, A., J. Oszmianski, and R. Czemerys. 2007. Antioxidant activity and phenolic compounds in 32 selected herbs. Food Chemistry 105:940-949. 